prof. dr hab. Kazimierz GÓRKA

Wydział Finansów, Uniwersytet Ekonomiczny w Krakowie

e-mail: gorkak@uek.krakow.pl

dr hab. inż. Marcin LUSZCZYK, prof. PO

Wydział Ekonomii i Zarządzania, Politechnika Opolska

e-mail:m.luszczyk@po.opole.pl

DOI: $10.15290 /$ ose.2017.01.85.02

\title{
BADANIA NAD ROZWOJEM TRWALYM W POLSKICH OŚRODKACH NAUKOWYCH
}

\begin{abstract}
Streszczenie
Artykuł stanowi próbę podsumowania dotychczasowych badań w zakresie rozwoju trwałego w polskich ośrodkach naukowych, jest również kontynuacją i uzupełnieniem prac zrealizowanych w 2009 roku przez Tadeusza Borysa i Stanisława Czaję. Zdaniem autorów, obserwowany wzrost zainteresowania problematyka, uzyskiwane awanse naukowe i stopniowe wdrażanie elementów rozwoju trwałego są podstawą do pozytywnej oceny dotychczasowych prac. Pewien niepokój mogą budzić: niedostatek pełnej i rzetelnej wiedzy na temat rozwoju trwałego w społeczeństwie, krótkowzroczne decyzje polityków promujące wzrost gospodarczy, zamiast dazżenia do poprawy jakości życia, nadal nierozstrzygnięte spory dotyczące terminologii rozwoju trwałego i widoczna luka pokoleniowa. Niekorzystnej tendencji może zaradzić dalsza, intensywna edukacja społeczeństwa i promocja badań stosowanych.
\end{abstract}

Słowa kluczowe: rozwój trwały, badania naukowe

RESEARCH ON SUSTAINABLE DEVELOPMENT IN POLISH SCIENTIFIC CENTRES

\section{Summary}

The paper is an attempt to summarise the current research in the field of sustainable development in Polish scientific centers. It is also a continuation of the work done in 2009 by Tadeusz Borys and Stanisław Czaja. The observed increased interest in the issue, scientific titles obtained by the authors, and gradual implementation of the elements of sustainable development seem to justify a positive assessment of the previous work. What may cause some concern, however, is lack of full and accurate knowledge about sustainable development among the general public, short-sighted political decisions that promote economic growth instead of striving to improve the quality of life, the still unresolved debate on the terminology concerning sustainable development, as well as the visible generation gap. These unfavourable tendencies could be remedied by further intensive public education and promotion of applied research.

Key words: sustainable development, scientific research

JEL: Q01, I20 


\section{Wstęp}

Pierwotnie koncepcja ekorozwoju, a obecnie rozwoju trwałego już od ponad pół wieku jest przedmiotem licznych badań w polskich ośrodkach naukowych. Wprawdzie powoli, lecz systematycznie, wzrasta zainteresowanie tą problematyka. Mimo poszerzającego się grona zainteresowanych, zarówno na świecie, jak i w Polsce jeszcze nie udało się rozstrzygnać zasadniczej kwestii, w jaki sposób trwale i w zgodzie ze środowiskiem naturalnym rozwijać społeczeństwo i gospodarkę. Ponadto, w Polsce w dalszym ciągu jest nierozstrzygnięty spór o terminologię rozwoju trwałego.

Artykuł jest próba podsumowania dotychczasowych badań w zakresie rozwoju trwałego w polskich ośrodkach naukowych, zarazem stanowi kontynuację i uzupełnienie prac podjętych przez Tadeusza Borysa i Stanisława Czaję, którzy w 2009 roku zrealizowali już podobną kwerendę.

\section{Tło historyczne koncepcji rozwoju trwałego}

Zasada trwałości (zrównoważenia) rozwoju po raz pierwszy została sformułowana w 1713 roku przez Hansa Carla von Carlowitza. Otóż arystokrata stwierdził, że zasoby leśne są największym skarbem Saksonii, a prawidłowa gospodarka polega na sadzeniu nowych drzew w miejsce już wyciętych. Tego rodzaju działalność: wymaga najwiekszego kunsztu, nauki, pilności i pryygotowania tutejszej ziemi, aby ustanowic i utrwalic taki

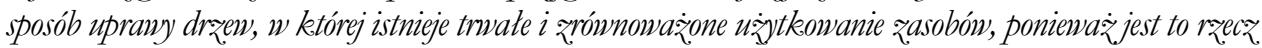
niezbedna, bez której kraj nie może istnieć [Carlowitz, 2009, s. 65]. Wprawdzie osiemnastowieczna reguła odnosiła się wyłącznie do gospodarki leśnej, ale należy odnotować fakt, że już wówczas zwrócono uwagę na potrzebę trwałego i zrównoważonego gospodarowania dobrami.

Problem zanieczyszczenia środowiska został zauważony już w 1885 roku w Londynie. Wówczas źródłem zanieczyszczenia było spalanie węgla. W latach sześćdziesiątych XX wieku problem zanieczyszczeń został uznany przez ekonomistów za poważne zagrożenie dobrobytu społecznego. Na początku lat siedemdziesiątych XX wieku straty w gospodarce Stanów Zjednoczonych, spowodowane zanieczyszczeniem środowiska, były określane na co najmniej 1-2 \% dochodu narodowego [Herer, Sadowski, 1989, s. 156], a w Niemczech na około 5\%. W Polsce straty ekologiczne wyniosły w 1995 roku średnio około 11\% produktu krajowego brutto, a w rejonach wysoko uprzemysłowionych o dużym stopniu skażenia środowiska sięgały nawet 20\% [Górka, 1997, s. 146]. Z kolei, koszty ochrony środowiska wahały się w latach osiemdziesiątych XX wieku w krajach OECD od 0,5-2\% dochodu narodowego. Według Wasilija Leontiefa, utrzymanie poziomu zanieczyszczeń z 1970 roku w najbliższym czasie będzie wymagać w krajach wysoko rozwiniętych nakładów na ochronę środowiska przynajmniej w wysokości 2,5\% PKB [Leontief, 1984, s. 823].

W 1968 roku, za sprawą sekretarza generalnego ONZ U Thanta, dyskusja dotycząca kierunków dalszego rozwoju społeczno-gospodarczego świata nabrała tempa, chociaż zaprezentowane wówczas podejście jest kojarzone z ekorozwojem (ecodevelopment) 
- wąskim ujęciem współcześnie rozumianego rozwoju trwałego. W rezolucji Zgromadzenia Ogólnego ONZ pt.: „Problemy środowiska ludzkiego” zwrócono uwagę na konieczność podjęcia wysiłków na rzecz ochrony środowiska i unikania zagrożeń dotyczacych rozwoju cywilizacji przez powiazanie zaawansowanych technologii z wymogami środowiska naturalnego, jak również zapobiegania erozji gleb i bezplanowej urbanizacji utraty bioróżnorodności [Problems..., 1969, s. 2].

Podczas konferencji w Sztokholmie w 1972 roku ponownie wyrażono potrzebę uwzględnienia ochrony środowiska w dalszym rozwoju społeczno-gospodarczym świata. Odrzucono wtedy tradycyjną koncepcję rozwoju gospodarczego, pojętego wyłącznie jako wzrost dochodu narodowego, na rzecz działań zmierzających do realizacji konkretnych celów społecznych. Podkreślono, że człowiek ma podstawowe prawo do wolności, równouprawnienia i należytych warunków życia oraz ponosi obowiązek ochrony środowiska wobec obecnych i przyszłych pokoleń. Ponadto, w raporcie stwierdzono, że rozwój społeczno-gospodarczy jest niezbędny do zapewnienia sprzyjających warunków i poprawy jakości życia człowieka. Jednak rozwój ten nie może odbywać się kosztem środowiska naturalnego [Report..., 1972, s. 4].

Ważnym etapem w doprecyzowaniu i zrozumieniu pojęcia trwałego wzrostu była publikacja raportu przygotowanego pod przewodnictwem Gro Harlem Brundtland przez Światową Komisję do spraw Środowiska i Rozwoju [Brundtland, 1991, s. 41]. Uznano wówczas, że rozwój trwały to taki rozwój, który zaspokaja potrzeby obecnego pokolenia bez pozbawiania możliwości przyszłych pokoleń do zaspokajania ich potrzeb. Odwołuje się on do następujących kluczowych koncepcji:

- zaspokajanie potrzeb mających priorytetowe znaczenie, czyli potrzeb podstawowych;

- $\quad$ znoszenie barier nałożonych przez stan technologii i organizacji społecznej na zdolność środowiska do zaspokojenia potrzeb obecnych i przyszłych pokoleń.

\section{Okres inicjowania badań nad rozwojem trwałym w Polsce}

Badania nad rozwojem trwałym w Polsce również mają długą tradycję. Jeszcze na początku lat sześćdziesiątych XX wieku dominował, zgodnie z radykalną wersją antropocentryzmu, pogląd o braku potrzeby troski o przyszłe pokolenia, ponieważ nauka i myśl techniczna potrafią złagodzić negatywne skutki rozwoju cywilizacyjnego [Kuzior, 2006, s. 71-72; Piątek, 1998]. Podejście takie jednoznacznie potwierdzały słowa Walerego Goetla co technika zepsuje, to technika naprawi [Górka, 2013, s. 18].

Swego rodzaju prolog - etap wstępny - w procesie urzeczywistniania nowego modelu rozwoju społeczno-gospodarczego miał swoje początki w połowie lat sześćdziesiątych XX wieku. Wówczas pojawiły się pierwsze publikacje Walerego Goetla z zakresu sozologii - nauki o ochronie środowiska naturalnego jako środowiska życia człowieka [Goetel, 1966, s. 473-482]. Obszar zainteresowań, zapomnianej już nieco, sozologii objął badania naturalnych i wynikających z działalności człowieka właściwości elementów przyrody nieożywionej i ożywionej, ich wpływu na stan zdrowia człowieka oraz pozostałych gatunków flory oraz fauny [Dołęga, 2000, s. 296-297]. 
Przełom lat sześćdziesiątych i siedemdziesiątych XX wieku to pierwszy okres, umownie nazwany etapem inspiracji, kiedy to w polskich ośrodkach naukowych narastało zainteresowanie nowym paradygmatem rozwoju i były dokonywane pierwsze próby jego identyfikacji. Bodźcem do podjęcia prac były niewattpliwie raport U’Thanta z 1968 roku i raporty dla Klubu Rzymskiego - pierwszy opublikowany w 1972 roku i drugi w 1974 roku. Wówczas to zarysowały się dwa zasadnicze kierunki badań. Pierwszy z nich ściśle nawiązuje do raportów dla Klubu Rzymskiego i wnioskowanej na tej podstawie koncepcji wærostu zerowego ${ }^{1}$, drugi zaś ma swoje źródło w raportach U’Thanta i dotyczy ekorozwoju. Współcześnie ani jeden, ani drugi kierunek badań nie budzi wielkich emocji wśród naukowców, chociaż jeszcze w latach siedemdziesiątych i osiemdziesiątych, za sprawą publikacji m.in. Stefana Kozłowskiego, ekorozwój zdobył w Polsce pewną popularność. Należy przypomnieć, że ekorozwój to: taki przęieieg nieuchronnego i pożadanego rozwoju gospodarczego, który nie narusza a by w sposób istotny i nieodwracalny środowiska sycia czৃtowieka, nie doprowadzatby do degradacii biosfery, który godzitby prawa prayrody, ekonomii $i$ kultury [Poskrobko, 1998, s. 75; Kozłowski, 1996]. Ekorozwój z definicji koncentruje się na relacjach zachodzących w układzie gospodarka - środowisko i jest uznawany wyłącznie za wąskie ujęcie rozwoju trwałego.

Należy podkreślić, że mimo rosnącego zainteresowania aspektem środowiskowym wzrostu gospodarczego, pierwsze publikacje z tego zakresu były dość ostrożne, przybliżały jedynie zagadnienia poruszane w literaturze światowej i zasadniczo nie wnosiły nowych elementów do badań nad uwarunkowanym ekologicznie rozwojem społeczno-gospodarczym. Wpływ na opisany stan badań miały: niechętny stosunek władz państwowych do wszelkiej krytyki, silna wówczas antropopresja, nieracjonalne zarządzanie zasobami naturalnymi i nieefektywny model gospodarki centralnie sterowanej. Ogłoszony w grudniu 1981 roku stan wojenny i jego następstwa spowodowały dodatkowe ograniczenia w swobodzie badań naukowych. Od połowy lat osiemdziesiątych badania nad rozwojem trwałym nasiliły się. Pojawiły się ważne publikacje: Adama Ginsberta-Geberta, Anny Jankowskiej-Kłapkowskiej, Stefana Kozłowskiego, Marka Bonenberga i Eugeniusza Kośmickiego. Dużą rolę w upowszechnianiu problematyki ekorozwoju odegrały wówczas czasopisma „Człowiek i Światopogląd” oraz „Aura” [Borys, Czaja, 2009, s. 63].

Bezpośrednio po publikacji raportu G.H. Brundtland, mamy do czynienia z etapem dojrzewania. Podjęto wtedy w Polsce szereg prac zmierzających do doprecyzowania nazewnictwa i warstwy poznawczej. Warto przy tym podkreślić, że zanim upowszechniło się pojęcie zrównoważony rozwój, dość długo operowano terminem rozwój samopodtrzymujący. W nowym wówczas paradygmacie Sustainable Development poszerzono dotychczasowy obszar zainteresowań o wymiar społeczny. Dalsze prace, podjęte w szczególności po Szczycie Ziemi w Rio de Janeiro, spowodowały, że współcześnie model Sustainable Development w najszerszym ujęciu jest kojarzony z ładem zintegrowanym. Obejmuje on sześć kategorii/wymiarów, a mianowicie: gospodarczą, spo-

${ }^{1}$ Pomysłodawcą koncepcji zerowego wzrostu był Ezra Mishan, który już w 1967 roku zwrócił uwagę na społeczne i środowiskowe koszty wzrostu gospodarczego i boomu demograficznego [Mishan, 1967]. 
łeczna, ekologiczna, przestrzenna, polityczno-instytucjonalną oraz etyczno-moralną. Rozważania w zakresie rozwoju trwałego są prowadzone nawet $z$ uwzględnieniem kategorii czasu [Czaja, 2011, s. 59-74], a w ostatnim okresie pojawia się dodatkowo kategoria kulturalna [Kiełczewski, 2013, s. 135-143; Górka, Łuszczyk, 2014, s. 25-32]. Często niedostrzegany, niekiedy kontrowersyjny etyczno-moralny wymiar rozwoju trwałego wynika z samej definicji. Rozwój trwały opiera się przecież na koncepcji sprawiedliwości społecznej, odwołującej się również do wartości pozamaterialnych - duchowych. Etyka współczesnego społeczeństwa musi więc opierać się na szacunku dla człowieka i respektować prawa przyszłych pokoleń, które także będą chciały z godnością realizować swoje potrzeby. W tym znaczeniu działania współczesnego pokolenia decydują o życiu i rozwoju przyszłych społeczeństw. Współczesne pokolenia są zatem odpowiedzialne za zachowanie stanu środowiska i jego zdolności do zaspokajania potrzeb przyszłych pokoleń. Obowiązek ten ma charakter wyłącznie moralny, gdyż nieistniejące jeszcze pokolenia nie dysponują odpowiednimi narzędziami ani możliwościami egzekwowania swoich praw [Jonas, 1996, s. 57]. Ostatnim elementem paradygmatu rozwoju trwałego jest system wartości, który stanowi fundament i spoiwo nowego wzorca rozwoju. Prowadzone dotąd badania pozwalają uznać za słuszną tezę, że wybór umiarkowanej wersji antropocentryzmu jako aksjologicznej podstawy rozwoju trwałego jest uzasadniony². Takie podejście ustala bowiem relacje międzyludzkie oraz zależności pomiędzy człowiekiem a środowiskiem, gwarantuje właściwy zakres odpowiedzialności między- i wewnątrzpokoleniowej, wyraźnie akcentuje nadrzędne miejsce człowieka na Ziemi, lecz jednocześnie w imię sprawiedliwości wewnątrz- i międzypokoleniowej zapewnia należne poszanowanie środowiska naturalnego. W tym przypadku drugorzędne znaczenie ma wyznawany światopogląd, ponieważ ten zwłaszcza odwołuje się do: sympatii politycznych, przekonań religijnych, kwestii dotyczących kultury i sztuki.

\section{Okres dojrzałości}

Okres bezpośrednio przed Szczytem Ziemi w Rio de Janeiro to również początek etapu fascynacji rozwojem trwałym. W Polsce wypracowano wówczas podstawy ekonomii ekologicznej i polityki ochrony środowiska naturalnego. Podjęto pierwsze badania mające na celu „zazielenienie” statystyki i rachunku kosztów działalności gospodarczej, które ujmuje ujemne efekty zewnętrzne. Transformacja ustrojowa i gospodarcza sprzyjała wówczas wzrostowi zainteresowania społeczeństwa zagadnieniami ochrony środowiska, które nabrały nowego wymiaru. Efektem prac Podzespołu do spraw Ekologii (tzw. zielonego podstolika) Okrąłego Stołu było określenie ram instytucjonalnych i prawnych ochrony środowiska w Polsce, jak również uwzględnienie kwestii środowiskowych w procesie transformacji ustrojowej i gospodarczej. Przygotowano wówczas dokument pt.: „Polityka Ekologiczna Państwa”, który uwzględniał postula-

2 Intensywne prace na ten temat były prowadzone już przed laty m.in. przez Tadeusza Borysa [2004, s. 55-65; 2010, s. 57-76]. 
ty strony społecznej i ustalał program transformacji od energo- i materiałochłonnej gospodarki centralnie sterowanej, przez etap stabilizacji i poprawy efektywności gospodarowania zasobami naturalnymi, aż do ekorozwoju [Uchwała..., 1991]. W środowisku akademickim dokonują się przeobrażenia, które przyniosły przede wszystkim efekty w postaci nowych kierunków i specjalności zawodowych oraz konsolidację naukowców podejmujących problematykę ekologiczna. W 1991 roku został powołany Polski Oddział Europejskiego Stowarzyszenia Ekonomistów Środowiska i Zasobów Naturalnych (dziś Polskie Stowarzyszenie Ekonomistów Środowiska i Zasobów Naturalnych), a którego członkowie reprezentują wszystkie ważniejsze ośrodki akademickie w Polsce. Od 1992 roku działa również Fundacja Ekonomistów Środowiska i Zasobów Naturalnych, wspierająca działalność Stowarzyszenia i będąca wydawcą m.in., ukazującego się od 1992 roku, czasopisma „Ekonomia i Środowisko”.

Od Szczytu Ziemi mamy do czynienia w zasadzie z niezakończonym jeszcze etapem implementacji idei rozwoju trwałego. Stosunkowo liczne już grono specjalistów (w zjeździe założycielskim Polskiego Oddziału ESEŚiZN uczestniczyło około stu ekonomistów z całej Polski) podjęło prace nad wdrażaniem idei rozwoju trwałego. Pracom wdrożeniowym miały sprzyjać seminaria i konferencje organizowane przez wiodące ośrodki akademickie zajmujące się rozwojem trwałym, w tym m.in. z: Białegostoku, Krakowa, Wrocławia i Jeleniej Góry. Działania wdrożeniowe dotyczyły m.in. następujących kwestii:

- $\quad$ wprowadzanie kategorii rozwoju trwałego do programów strategicznych różnych szczebli;

- uzupełnienie systemów monitoringu ekologicznego o wskaźniki rozwoju trwałego;

- opracowanie metodyki i programów rozwoju trwałego w skali lokalnej i regionalnej;

- $\quad$ przygotowanie zasad inwentaryzacji zasobów przyrodniczych gmin;

- prowadzenie pogłębionych badań nad istotą rozwoju trwałego [Borys, Czaja, 2009, s. 64].

Jednocześnie ideą rozwoju trwałego zainteresowali się wówczas specjaliści z innych dziedzin nauki, praktycy życia gospodarczego i politycy. W przemyśle wprowadzono standard BAT (Best Available Technology), którego celem jest ograniczenie emisji zanieczyszczeń. Nauki medyczne i filozofia, zamiast „wyścigu szczurów” i fast food, promują: zdrowy styl życia, aktywny kontakt z przyrodą i slow food. Współcześnie mamy także zrównoważony transport, gospodarkę przestrzenną $\mathrm{i}$ turystykę.

To szerokie zainteresowanie rozwojem trwałym $z$ jednej strony sprzyja upowszechnieniu idei, zwraca uwagę społeczeństwa na zagrożenia wynikające z nieodpowiedniego stanu środowiska naturalnego i na negatywne konsekwencje ilościowego wzrostu gospodarczego, z drugiej zaś jest jedną z przyczyn utrzymujących się kontrowersji i pewnych watpliwości. Jak w każdym istotnym zagadnieniu, tak i w kwestii upowszechnienia oraz wdrażania rozwoju trwałego pojawiło się również grono sceptyków nieprzychylnych koniecznym zmianom - ten okres umownie można nazwać etapem wątpliwości. 
Nieład terminologiczny, który cechuje polskie badania nad rozwojem trwałym, potęguje stale rosnące zainteresowanie zagadnieniem ze strony przedstawicieli różnych dyscyplin naukowych. Dynamiczny wzrost liczby interpretacji pojęcia rozwoju trwałego jednak wcale nie sprzyja właściwemu jego zrozumieniu, co przypuszczalnie wiąże się $\mathrm{z}$ faktem, że ką̧da recepcja jest interpretacja na miare wiedšy, przelkonań i potrzeb podejmujacych ja podmiotów [Papuziński, 2013, s. 6]. Brak konsensusu wśród specjalistów w żaden sposób nie musi być oznaką twórczego rozwoju dyscypliny, natomiast służy pojawiającej się od czasu do czasu krytyce ze strony pozostałych zainteresowanych zagadnieniem [Górka, 2013, s. 11]. Niekończące się spory oraz negocjacje terminologiczne i definicyjne już niemal dziesięć lat temu trafnie podsumował Tadeusz Borys: odnosi sie cresto wrażenie, jakby dyskusja byta nadal w fazie poczatkowej i jakby poszcrególne śodowiska nie do końca byly zainteresowane wprowadzaniem tadu w tej dyskusji [Borys, 2005, s. 65]. Mimo upływu dekady od tej konstatacji, nie widać finału uzgodnień. Można nawet sądzić, że niektórzy autorzy z samej tylko przekory trwają przy upowszechnionej terminologii.

Niezależnie od trwających starań w zakresie doprecyzowania definicji i samego tłumaczenia pojęcia, podejmowane są działania zmierzające do konkretyzacji poszczególnych kategorii rozwoju trwałego. Bez uściślenia sposobów realizacji rozwoju trwałego pozostaje on nadal teoretycznym paradygmatem, przez niektórych sceptyków uznawanym za koncepcję mętna, niekonkretną, wyłącznie postulatywną, nienaukowă będącą wręcz oszustwem. W łagodniejszych wypowiedziach wątpliwości są wyrażane jako dylemat: czy rozwój ten jest utopia, czy realną możliwością [Borys, 2011, s. 76; Sztumski, 2008, s. 133-139; Zacher, 2008, s. 63-68]? Jak zauważyli Tadeusz Borys i Stanisław Czaja, niektórzy autorzy w swoich publikacjach pomijają etyczne podstawy rozwoju trwałego i zasadniczy sens jakości życia, jakim jest równoważenie sfery: fizycznej, psychicznej, uczuciowej i duchowej [Borys, Czaja, 2009, s. 51-52].

Głosy sceptyków i brak porozumienia wśród samych zainteresowanych rozwojem trwałym są zarazem argumentem dla osób, które dość krótkowzrocznie uzależniają poprawę jakości życia włącznie od wzrostu gospodarczego i intensyfikacji konsumpcji. Dla nich nowy model rozwoju cywilizacyjnego jest tylko wymysłem grupy naukowców i nielicznych polityków, który przeszkadza w osiagnięciu wyższego poziomu dobrobytu materialnego. Tej grupie osób, zwykle niechętnej wyrzeczeniom na rzecz środowiska naturalnego, należałoby przypomnieć renesansowe ostrzeżenie „Polak mądry po szkodzie".

\section{Okres stopniowego nasycenia}

Niezależnie od pojawiających się raz po raz wątpliwości, głosów sceptyków i specjalistów marketingu zachęcających do maksymalizacji konsumpcji, w drugiej połowie lat dziewięćdziesiątych XX wieku rozpoczął się i trwa do dziś etap edukacji z zakresu rozwoju trwałego. Co najmniej podstawową wiedzę o nowym paradygmacie uzyskało wielu studentów kierunków ekonomicznych. Ponadto, wielu ekonomistów zdecydowało się na podjęcie własnych badań w zakresie rozwoju trwałego. Efektem ich prac są nie tylko nowe publikacje, ale również uzyskane stopnie i tytuły naukowe. Niewątpli- 
wie, źródłem sukcesów w edukacji były liczne konferencje i realizowane programy. Wśród nich warto wymienić: cykl konferencji pt.: „Edukacja dla zrównoważonego rozwoju”, organizowanych przez Katedrę Zarządzania Jakością i Środowiskiem Jeleniogórskiego Wydziału Ekonomii, Zarządzania i Turystyki Uniwersytetu Ekonomicznego we Wrocławiu, cykl konferencji organizowanych przez ośrodek białostocki i równolegle realizowany przez Wyższą Szkołę Ekonomiczną w Białymstoku „Program upowszechniania osiagnięć nauki z zakresu zrównoważonego rozwoju i gospodarki opartej na wiedzy”.

Naturalną konsekwencją upowszechniania wiedzy jest rozwój autorskich badań nad nowym paradygmatem. Wprawdzie nie wszystkie kwestie terminologiczne zostały jeszcze rozstrzygnięte, jednak inicjowane badania coraz częściej dotyczą już wąskich zagadnień. Nierzadko ich autorami i wykonawcami są młodzi naukowcy - studenci i wychowankowie profesorów - prekursorów badań nad rozwojem trwałym w Polsce. Trwający do dziś okres umownie można nazwać etapem specjalizacji.

Tadeusz Borys i Stanisław Czaja w swojej publikacji wyróżnili 17 ośrodków akademickich oraz 31 uczelni wyższych i instytucji, w których 71 osób, pod koniec pierwszej dekady XXI wieku, aktywnie prowadziło badania nad rozwojem trwałym. W 2015 i 2016 roku wyraźnie poszerzyło się grono specjalistów z tego zakresu. Prace naukowe w zakresie rozwoju trwałego w latach 2014-2016 były prowadzone przez co najmniej 154 osoby skupione na 51 uczelniach wyższych i instytucjach naukowych w 21 ośrodkach (tabela 1.). Prezentowane zestawienie przygotowano na podstawie publikacji naukowych z zakresu rozwoju trwałego, uczestnictwa w konferencjach i członkostwa w komitetach naukowych oraz informacji zawartych w internetowych bazach danych Ośrodka Przetwarzania Informacji [Ludzie nauki..., 2016]. Należy przypuszczać, że lista polskich specjalistów z zakresu rozwoju trwałego jest jeszcze dłuższa, bowiem samo tylko Polskie Stowarzyszenie Ekonomistów Środowiska i Zasobów Naturalnych liczy ponad 200 członków.

TABELA 1.

\section{Badania nad rozwojem trwałym w Polsce - podsumowanie}

\begin{tabular}{|l|l|l|l|}
\hline \multicolumn{1}{|c|}{ Miasto } & \multicolumn{1}{|c|}{ Instytucja } & \multicolumn{1}{|c|}{ Przedstawiciele } & \multicolumn{1}{|c|}{$\begin{array}{c}\text { Główne kierunki badań / } \\
\text { Specjalności }\end{array}$} \\
\hline $\begin{array}{l}\text { Biała Podla- } \\
\text { ska }\end{array}$ & $\begin{array}{l}\text { Państwowa Szkoła Wyższa } \\
\text { im. Papieża Jana Pawła II } \\
\text { w Białej Podlaskiej }\end{array}$ & $\begin{array}{l}\text { prof. dr hab. Bogdan } \\
\text { Kościk }\end{array}$ & $\begin{array}{l}\text { wielofunkcyjny i zrównowa- } \\
\text { żony rozwój obszarów wiej- } \\
\text { skich, wycena środowiska } \\
\text { naturalnego }\end{array}$ \\
\hline \multirow{2}{*}{ Białystok } & Politechnika Białostocka & $\begin{array}{l}\text { prof. dr hab. Rafał Miła- } \\
\text { szewski }\end{array}$ & gospodarka wodna \\
\cline { 3 - 4 } & dr hab. Joanna Ejdys & $\begin{array}{l}\text { ekonomika ochrony środo- } \\
\text { wiska, zarządzanie ochrona } \\
\text { śodowiska }\end{array}$ \\
\cline { 3 - 4 } & & ekonomika turystyki \\
\cline { 3 - 4 } & & $\begin{array}{l}\text { dr hab. Mikołaj Jalinik } \\
\text { luk hab. Aleksander Kiry- }\end{array}$ & $\begin{array}{l}\text { inżynieria i ochrona środo- } \\
\text { wiska }\end{array}$ \\
\cline { 3 - 4 } & & dr hab. Iwona Skoczko & $\begin{array}{l}\text { inżynieria i ochrona środo- } \\
\text { wiska }\end{array}$ \\
\cline { 3 - 4 } & & prawo ochrony środowiska \\
\hline
\end{tabular}




\begin{tabular}{|c|c|c|c|}
\hline & & dr Elżbieta Broniewicz & $\begin{array}{l}\text { ekonomika środowiska natu- } \\
\text { ralnego }\end{array}$ \\
\hline & & $\begin{array}{l}\text { dr inż. Joanna Godlew- } \\
\text { ska }\end{array}$ & $\begin{array}{l}\text { ekonomika ochrony środo- } \\
\text { wiska, zarządzanie ochroną } \\
\text { środowiska }\end{array}$ \\
\hline & & dr Halina Kiryluk & $\begin{array}{l}\text { ekonomika turystyki, zarza- } \\
\text { dzanie turystyką }\end{array}$ \\
\hline & & dr Ewa Rauba & $\begin{array}{l}\text { ekonomika ochrony środo- } \\
\text { wiska }\end{array}$ \\
\hline & & dr Krystyna Rauba & $\begin{array}{l}\text { ekonomika ochrony środo- } \\
\text { wiska }\end{array}$ \\
\hline & & dr Małgorzata Rauba & gospodarka wodna \\
\hline & Uniwersytet w Białymstoku & $\begin{array}{l}\text { prof. dr hab. Bazyli Po- } \\
\text { skrobko } \\
\text { (obecnie: Wyższa Szkoła } \\
\text { Ekonomiczna w Białym- } \\
\text { stoku) }\end{array}$ & $\begin{array}{l}\text { ekonomika i zarządzanie } \\
\text { ochrona środowiska, gospo- } \\
\text { darka oparta na wiedzy }\end{array}$ \\
\hline & & $\begin{array}{l}\text { prof. dr hab. Andrzej } \\
\text { Bocian }\end{array}$ & $\begin{array}{l}\text { makroekonomia, polityka } \\
\text { gospodarcza }\end{array}$ \\
\hline & & $\begin{array}{l}\text { dr hab. Artur Bołtro- } \\
\text { miuk }\end{array}$ & $\begin{array}{l}\text { ekonomika środowiska, eko- } \\
\text { nomika rolnictwa }\end{array}$ \\
\hline & & dr hab. Ewa Czech & prawo ochrony środowiska \\
\hline & & $\begin{array}{l}\text { dr hab. Dariusz Kieł- } \\
\text { czewski }\end{array}$ & $\begin{array}{l}\text { ekofilozofia, konsumpcja } \\
\text { zrównoważona }\end{array}$ \\
\hline & & dr Anna Busłowska & transport zrównoważony \\
\hline & & dr Tomasz Poskrobko & $\begin{array}{l}\text { ekonomika środowiska natu- } \\
\text { ralnego }\end{array}$ \\
\hline & $\begin{array}{l}\text { Wyższa Szkoła Ekono- } \\
\text { miczna w Białymstoku }\end{array}$ & $\begin{array}{l}\text { dr Bogumiła Powi- } \\
\text { chrowska }\end{array}$ & gospodarowanie wiedzą \\
\hline & & \begin{tabular}{|l|} 
dr Edyta Sidorczuk-Pie- \\
traszko
\end{tabular} & $\begin{array}{l}\text { ekonomia środowiska i zaso- } \\
\text { bów naturalnych }\end{array}$ \\
\hline & $\begin{array}{l}\text { Wyższa Szkoła Finansów } \\
\text { i Zarządzania w Białymstoku }\end{array}$ & $\begin{array}{l}\text { dr Anna Iwacewicz-Or- } \\
\text { łowska }\end{array}$ & $\begin{array}{l}\text { rozwój obszarów cennych } \\
\text { przyrodniczo }\end{array}$ \\
\hline Bielsko-Biała & $\begin{array}{l}\text { Wyższa Szkoła Ekono- } \\
\text { miczno-Humanistyczna } \\
\text { w Bielsku-Białej }\end{array}$ & $\begin{array}{l}\text { dr hab. Wiesław Sztum- } \\
\text { ski }\end{array}$ & filozofia przyrodoznawstwa \\
\hline Bydgoszcz & $\begin{array}{l}\text { Uniwersytet Kazimierza } \\
\text { Wielkiego w Bydgoszczy }\end{array}$ & $\begin{array}{l}\text { dr hab. Andrzej Papu- } \\
\text { ziński }\end{array}$ & $\begin{array}{l}\text { filozofia ekologiczna, poli- } \\
\text { tyka ekologiczna }\end{array}$ \\
\hline & & $\begin{array}{l}\text { dr hab. Zbigniew Bu- } \\
\text { kowski }\end{array}$ & prawo ochrony środowiska \\
\hline $\begin{array}{l}\text { Dábrowa } \\
\text { Górnicza }\end{array}$ & $\begin{array}{l}\text { Wyższa Szkoła Biznesu } \\
\text { w Dąbrowie Górniczej }\end{array}$ & $\begin{array}{l}\text { prof. dr hab. Franciszek } \\
\text { Piontek }\end{array}$ & $\begin{array}{l}\text { ekonomia środowiskowa, } \\
\text { zarządzanie rozwojem trwa- } \\
\text { łym }\end{array}$ \\
\hline & & dr hab. Barbara Piontek & $\begin{array}{l}\text { zarządzanie rozwojem zrów- } \\
\text { noważonym }\end{array}$ \\
\hline & & $\begin{array}{l}\text { dr hab. Urszula Wassikie- } \\
\text { wicz-Rusnak }\end{array}$ & $\begin{array}{l}\text { ekonomika i organizacja } \\
\text { przedsiębiorstw, ekonomika } \\
\text { ochrony środowiska }\end{array}$ \\
\hline & & dr Wojciech Piontek & $\begin{array}{l}\text { ekonomika ochrony środo- } \\
\text { wiska }\end{array}$ \\
\hline
\end{tabular}




\begin{tabular}{|c|c|c|c|}
\hline \multirow[t]{4}{*}{ Gdańsk } & $\begin{array}{l}\text { Ateneum - Szkoła Wyższa } \\
\text { w Gdańsku }\end{array}$ & dr hab. Witold Toczyski & $\begin{array}{l}\text { planowanie regionalne, poli- } \\
\text { tyka społeczna }\end{array}$ \\
\hline & \multirow[t]{2}{*}{ Uniwersytet Gdański } & $\begin{array}{l}\text { dr hab. Mariusz Kistow- } \\
\text { ski }\end{array}$ & $\begin{array}{l}\text { ochrona środowiska, } \\
\text { teoria i praktyka rozwoju } \\
\text { trwałego }\end{array}$ \\
\hline & & $\begin{array}{l}\text { dr hab. Barbara Pawłow- } \\
\text { ska }\end{array}$ & ekonomika transportu \\
\hline & \begin{tabular}{|l} 
Wyższa Szkoła Turystyki \\
i Hotelarstwa w Gdańsku
\end{tabular} & dr hab. Jan Leśniak & $\begin{array}{l}\text { ekologiczne zarządzanie } \\
\text { przedsiębiorstwem, } \\
\text { ekonomika ochrony środo- } \\
\text { wiska }\end{array}$ \\
\hline \multirow[t]{3}{*}{ Gdynia } & \multirow[t]{3}{*}{ Akademia Morska w Gdyni } & $\begin{array}{l}\text { prof. dr hab. Piotr Przy- } \\
\text { byłowski }\end{array}$ & $\begin{array}{l}\text { towaroznawstwo artykułów } \\
\text { żywnościowych }\end{array}$ \\
\hline & & $\begin{array}{l}\text { dr hab. Adam Przyby- } \\
\text { łowski }\end{array}$ & transport zrównoważony \\
\hline & & dr Hanna Kruk & $\begin{array}{l}\text { gospodarka regionalna, eko- } \\
\text { nomia ekologiczna }\end{array}$ \\
\hline \multirow[t]{10}{*}{ Jelenia Góra } & \multirow[t]{10}{*}{$\begin{array}{l}\text { Wydział Zamiejscowy Uni- } \\
\text { wersytetu Ekonomicznego } \\
\text { we Wrocławiu }\end{array}$} & $\begin{array}{l}\text { prof. dr hab. Tadeusz } \\
\text { Borys } \\
\text { (obecnie: Uniwersytet } \\
\text { Zielonogórski) } \\
\end{array}$ & $\begin{array}{l}\text { kwalimetria, ekonomia } \\
\text { ochrony środowiska }\end{array}$ \\
\hline & & $\begin{array}{l}\text { prof. dr hab. Grażyna } \\
\text { Borys }\end{array}$ & $\begin{array}{l}\text { finanse, ekonomia ochrony } \\
\text { środowiska }\end{array}$ \\
\hline & & $\begin{array}{l}\text { dr hab. Zbigniew Przy- } \\
\text { była }\end{array}$ & $\begin{array}{l}\text { polityka regionalna, gospo- } \\
\text { darka przestrzenna }\end{array}$ \\
\hline & & dr hab. Adam Płachciak & $\begin{array}{l}\text { etyka środowiskowa, historia } \\
\text { filozofii }\end{array}$ \\
\hline & & dr Beata Bal-Domańska & $\begin{array}{l}\text { ekonometria, badania regio- } \\
\text { nalne }\end{array}$ \\
\hline & & dr Bartosz Bartniczak & $\begin{array}{l}\text { zarządzanie jakością i ochro- } \\
\text { ną środowiska }\end{array}$ \\
\hline & & $\begin{array}{l}\text { dr Marta Kusterka-Je- } \\
\text { fmańska }\end{array}$ & $\begin{array}{l}\text { zarządzanie jakością i ochro- } \\
\text { ną środowiska }\end{array}$ \\
\hline & & dr Michał Ptak & $\begin{array}{l}\text { zarządzanie jakością i ochro- } \\
\text { ną środowiska } \\
\end{array}$ \\
\hline & & dr Piotr Rogala & $\begin{array}{l}\text { etyka życia gospodarczego, } \\
\text { zarządzanie jakością }\end{array}$ \\
\hline & & $\begin{array}{l}\text { dr Sabina Zaremba- } \\
\text { Warnke }\end{array}$ & $\begin{array}{l}\text { marketing ekologiczny, sta- } \\
\text { tystyka }\end{array}$ \\
\hline \multirow[t]{5}{*}{ Katowice } & $\begin{array}{l}\text { Górnoślaska Wyższa Szko- } \\
\text { ła Handlowa } \\
\end{array}$ & $\begin{array}{l}\text { prof. dr hab. Ryszard } \\
\text { Janikowski }\end{array}$ & $\begin{array}{l}\text { inżynieria i ekonomia } \\
\text { ochrony środowiska }\end{array}$ \\
\hline & $\begin{array}{l}\text { Instytut Ekologii Terenów } \\
\text { Uprzemysłowionych w Ka- } \\
\text { towicach }\end{array}$ & dr Barbara Jaros & konsumpcja zrównoważona \\
\hline & \multirow[t]{3}{*}{\begin{tabular}{|l|} 
Uniwersytet Ekonomiczny \\
w Katowicach
\end{tabular}} & $\begin{array}{l}\text { prof. dr hab. Elżbieta } \\
\text { Lorek }\end{array}$ & $\begin{array}{l}\text { zarządzanie i ekonomika } \\
\text { środowiska naturalnego, } \\
\text { marketing ekologiczny }\end{array}$ \\
\hline & & dr Agnieszka Lorek & $\begin{array}{l}\text { ekonomika środowiskowa, } \\
\text { gospodarka miejska i regio- } \\
\text { nalna }\end{array}$ \\
\hline & & dr Arkadiusz Halama & $\begin{array}{l}\text { ekonomika ochrony środo- } \\
\text { wiska }\end{array}$ \\
\hline
\end{tabular}




\begin{tabular}{|c|c|c|c|}
\hline Koszalin & Politechnika Koszalińska & $\begin{array}{l}\text { dr hab. Jolanta Kondra- } \\
\text { towicz-Pozorska }\end{array}$ & $\begin{array}{l}\text { ekonomika środowiska i za- } \\
\text { sobów naturalnych }\end{array}$ \\
\hline \multirow[t]{20}{*}{ Kraków } & \multirow[t]{5}{*}{$\begin{array}{l}\text { Akademia Górniczo-Hutni- } \\
\text { cza }\end{array}$} & prof. dr hab. Ignacy Fiut & $\begin{array}{l}\text { estetyka współczesna, filo- } \\
\text { zofia środowiskowa }\end{array}$ \\
\hline & & dr hab. Leszek Preisner & $\begin{array}{l}\text { ekonomika ochrony środo- } \\
\text { wiska, zarządzanie ochroną } \\
\text { środowiska }\end{array}$ \\
\hline & & dr hab. Tadeusz Pindór & $\begin{array}{l}\text { ekonomika ochrony środo- } \\
\text { wiska i zasobów naturalnych }\end{array}$ \\
\hline & & dr Anna Dubel & $\begin{array}{l}\text { zarządzanie ochroną środo- } \\
\text { wiska }\end{array}$ \\
\hline & & dr Justyna Dyduch & $\begin{array}{l}\text { finansowanie ochrony śro- } \\
\text { dowiska }\end{array}$ \\
\hline & \multirow[t]{9}{*}{$\begin{array}{l}\text { Uniwersytet Ekonomiczny } \\
\text { w Krakowie }\end{array}$} & $\begin{array}{l}\text { prof. dr hab. Józefa Fa- } \\
\text { mielec }\end{array}$ & $\begin{array}{l}\text { ekonomika przemysłu, eko- } \\
\text { nomika ochrony środowiska }\end{array}$ \\
\hline & & $\begin{array}{l}\text { prof. dr hab. Kazimierz } \\
\text { Górka } \\
\text { (obecnie: Akademia Wy- } \\
\text { chowania Fizycznego } \\
\text { w Katowicach) } \\
\end{array}$ & $\begin{array}{l}\text { ekonomika przemysłu, eko- } \\
\text { nomika ochrony środowiska } \\
\text { i zasobów naturalnych }\end{array}$ \\
\hline & & $\begin{array}{l}\text { prof. dr hab. Zygmunt } \\
\text { Szymla }\end{array}$ & $\begin{array}{l}\text { gospodarka regionalna, poli- } \\
\text { tyka ekonomiczna }\end{array}$ \\
\hline & & dr hab. Piotr Małecki & $\begin{array}{l}\text { ekonomika ochrony środo- } \\
\text { wiska, podatki ekologiczne }\end{array}$ \\
\hline & & $\begin{array}{l}\begin{array}{l}\text { dr hab. Małgorzata Ko- } \\
\text { żuch }\end{array} \\
\end{array}$ & $\begin{array}{l}\text { ekonomika ochrony środo- } \\
\text { wiska }\end{array}$ \\
\hline & & dr Ksymena Rosiek & $\begin{array}{l}\text { gospodarka wodna, ekono- } \\
\text { mika ochrony środowiska }\end{array}$ \\
\hline & & dr Ivan Telega & $\begin{array}{l}\text { polityka przemysłowa i eko- } \\
\text { logiczna }\end{array}$ \\
\hline & & $\begin{array}{l}\text { dr Agnieszka Thier } \\
\text { (obecnie: Krajowa Izba } \\
\text { Gospodarcza „Przemysł } \\
\text { Rozlewniczy”) } \\
\end{array}$ & gospodarka wodna \\
\hline & & dr Maria Urbaniec & $\begin{array}{l}\text { zarządzanie ochrona środo- } \\
\text { wiska }\end{array}$ \\
\hline & \multirow[t]{2}{*}{ Uniwersytet Jagielloński } & $\begin{array}{l}\text { dr hab. Krzysztof Ber- } \\
\text { beka }\end{array}$ & $\begin{array}{l}\text { integracja europejska, eko- } \\
\text { nomika ochrony środowiska }\end{array}$ \\
\hline & & dr Marek Bonenberg & $\begin{array}{l}\text { etyka, filozofia środo- } \\
\text { wiskowa }\end{array}$ \\
\hline & $\begin{array}{l}\text { Uniwersytet Pedagogiczny } \\
\text { w Krakowie }\end{array}$ & dr Paulina Szyja & $\begin{array}{l}\text { zielona gospodarka, ekoin- } \\
\text { nowacje }\end{array}$ \\
\hline & \multirow[t]{3}{*}{$\begin{array}{l}\text { Uniwersytet Rolniczy } \\
\text { w Krakowie }\end{array}$} & dr Mariusz Dacko & $\begin{array}{l}\text { analiza rynku, wycena nie- } \\
\text { ruchomości }\end{array}$ \\
\hline & & dr Stanisław Famielec & gospodarka odpadami \\
\hline & & dr Katarzyna Kokoszka & $\begin{array}{l}\text { rozwój zrównoważony } \\
\text { terenów wiejskich }\end{array}$ \\
\hline \multirow[t]{3}{*}{ Lublin } & $\begin{array}{l}\text { Katolicki Uniwersytet Lu- } \\
\text { belski }\end{array}$ & $\begin{array}{l}\text { ks. prof. dr hab. Stani- } \\
\text { sław Zięba }\end{array}$ & $\begin{array}{l}\text { ekologia człowieka, filozofia } \\
\text { przyrody ożywionej }\end{array}$ \\
\hline & \multirow[t]{2}{*}{ Politechnika Lubelska } & $\begin{array}{l}\text { prof. dr hab. Lucjan } \\
\text { Pawłowski }\end{array}$ & $\begin{array}{l}\text { inżynieria i ochrona środowis- } \\
\mathrm{ka}\end{array}$ \\
\hline & & dr hab. Artur Pawłowski & rozwój trwały \\
\hline
\end{tabular}




\begin{tabular}{|c|c|c|c|}
\hline & $\begin{array}{l}\text { Uniwersytet Marii Curie- } \\
\text { Skłodowskiej w Lublinie }\end{array}$ & $\begin{array}{l}\text { dr hab. Agnieszka Lesz- } \\
\text { czyńska }\end{array}$ & $\begin{array}{l}\text { zarzaadzanie ochroną środo- } \\
\text { wiska }\end{array}$ \\
\hline \multirow[t]{7}{*}{ Łódź } & \multirow[t]{7}{*}{ Uniwersytet Lódzki } & $\begin{array}{l}\text { dr hab. Małgorzata Bur- } \\
\text { chard-Dziubińska }\end{array}$ & $\begin{array}{l}\text { ekonomika ochrony środo- } \\
\text { wiska, zarządzanie środowi- } \\
\text { skowe }\end{array}$ \\
\hline & & $\begin{array}{l}\text { dr hab. Jakub Kronen- } \\
\text { berg }\end{array}$ & usługi ekosystemów \\
\hline & & dr Elżbieta Antczak & ekonometria, statystyka \\
\hline & & dr Dominik Drzazga & gospodarka przestrzenna \\
\hline & & dr Dorota Michalak & problematyka zmian klimatu \\
\hline & & dr Urszula Motowidlak & $\begin{array}{l}\text { logistyka, transport zrówno- } \\
\text { ważony }\end{array}$ \\
\hline & & dr Agnieszka Rzeńca & $\begin{array}{l}\text { zarządzanie ochrona środo- } \\
\text { wiska, ekoinnowacje }\end{array}$ \\
\hline \multirow[t]{6}{*}{ Olsztyn } & \multirow[t]{6}{*}{$\begin{array}{l}\text { Uniwersytet Warmińsko- } \\
\text { Mazurski }\end{array}$} & $\begin{array}{l}\text { prof. dr hab. Zbigniew } \\
\text { Hull }\end{array}$ & filozofia ekologiczna \\
\hline & & $\begin{array}{l}\text { prof. dr hab. Teresa Ła- } \\
\text { guna }\end{array}$ & $\begin{array}{l}\text { ekonomika przestrzenna, eko- } \\
\text { nomika środowiska i zasobów } \\
\text { naturalnych }\end{array}$ \\
\hline & & dr hab. Piotr Krajewski & bioetyka \\
\hline & & $\begin{array}{l}\text { dr hab. Konrad Turkow- } \\
\text { ski }\end{array}$ & $\begin{array}{l}\text { ekonomika rybactwa, wyce- } \\
\text { na zasobów naturalnych }\end{array}$ \\
\hline & & dr Dariusz Laguna & gospodarka przestrzenna \\
\hline & & dr Wanda Laguna & $\begin{array}{l}\text { architektura krajobrazu, pla- } \\
\text { nowanie przestrzenne obsza- } \\
\text { rów wiejskich }\end{array}$ \\
\hline \multirow[t]{5}{*}{ Opole } & \multirow[t]{2}{*}{ Politechnika Opolska } & $\begin{array}{l}\text { prof. dr hab. Krzysztof } \\
\text { Malik }\end{array}$ & $\begin{array}{l}\text { ekonomika środowiska natu- } \\
\text { ralnego, zarządzanie ekologicz- } \\
\text { ne }\end{array}$ \\
\hline & & $\begin{array}{l}\text { dr. hab. Marcin Lusz- } \\
\text { czyk }\end{array}$ & $\begin{array}{l}\text { ekonomika środowiska natu- } \\
\text { ralnego, jakość życia }\end{array}$ \\
\hline & \multirow[t]{3}{*}{ Uniwersytet Opolski } & $\begin{array}{l}\text { prof. dr hab. Janusz } \\
\text { Słodczyk }\end{array}$ & $\begin{array}{l}\text { geografia ekonomiczna, pla- } \\
\text { nowanie przestrzenne }\end{array}$ \\
\hline & & dr Monika Paradowska & zrównoważony transport \\
\hline & & dr Bartosz Fortuński & $\begin{array}{l}\text { inżynieria i ochrona środowis- } \\
\text { ka, energetyka }\end{array}$ \\
\hline \multirow[t]{7}{*}{ Poznań } & \multirow[t]{2}{*}{$\begin{array}{l}\text { Uniwersytet im. Adama } \\
\text { Mickiewicza }\end{array}$} & $\begin{array}{l}\text { prof. dr hab. Andrzej } \\
\text { Mizgajski }\end{array}$ & $\begin{array}{l}\text { geografia, świadczenia eko- } \\
\text { systemów }\end{array}$ \\
\hline & & $\begin{array}{l}\text { dr Joanna Czerna-Gry- } \\
\text { giel }\end{array}$ & $\begin{array}{l}\text { ekonomika pracy, ekonomi- } \\
\text { ka rolnictwa }\end{array}$ \\
\hline & \multirow[t]{5}{*}{$\begin{array}{l}\text { Uniwersytet Przyrodniczy } \\
\text { w Poznaniu }\end{array}$} & $\begin{array}{l}\text { prof. dr hab. Włady- } \\
\text { sława Luczka-Bakuła }\end{array}$ & $\begin{array}{l}\text { ekonomika gospodarki żyw- } \\
\text { nościowej, ekonomika kon- } \\
\text { sumpcji }\end{array}$ \\
\hline & & $\begin{array}{l}\text { prof. dr hab. Janina } \\
\text { Zbierska }\end{array}$ & $\begin{array}{l}\text { ochrona środowiska, agroek- } \\
\text { ologia }\end{array}$ \\
\hline & & $\begin{array}{l}\text { dr hab. Barbara Hadry- } \\
\text { jańska }\end{array}$ & $\begin{array}{l}\text { ekonomiczne aspekty } \\
\text { ochrony środowiska }\end{array}$ \\
\hline & & $\begin{array}{l}\text { dr hab. Eugeniusz Ko- } \\
\text { śmicki }\end{array}$ & $\begin{array}{l}\text { metodyka nauk społecznych } \\
\text { i przyrodniczych, ekonomia } \\
\text { ekologiczna }\end{array}$ \\
\hline & & $\begin{array}{l}\text { dr hab. Dariusz Pień- } \\
\text { kowski }\end{array}$ & $\begin{array}{l}\text { ekonomika środowiska natu- } \\
\text { ralnego }\end{array}$ \\
\hline
\end{tabular}




\begin{tabular}{|c|c|c|c|}
\hline & & dr Anna Zbierska & $\begin{array}{l}\text { ochrona środowiska, zago- } \\
\text { spodarowanie przestrzenne }\end{array}$ \\
\hline & & dr Adam Zydroń & ekonomika leśnictwa \\
\hline & \begin{tabular}{|l|} 
Wyższa Szkoła Zarządzania \\
i Bankowości w Poznaniu \\
\end{tabular} & $\begin{array}{l}\text { prof. dr hab. Stanisław } \\
\text { Lojewski }\end{array}$ & $\begin{array}{l}\text { ekonomika zasobów natural- } \\
\text { nych i ochrony środowiska }\end{array}$ \\
\hline \multirow[t]{4}{*}{ Rzeszów } & Politechnika Rzeszowska & $\begin{array}{l}\text { prof. dr hab. Leszek } \\
\text { Woźniak }\end{array}$ & $\begin{array}{l}\text { zielona ekonomia, ekoinno- } \\
\text { wacje, zarządzanie ochroną } \\
\text { środowiska }\end{array}$ \\
\hline & \multirow[t]{3}{*}{ Uniwersytet Rzeszowski } & $\begin{array}{l}\text { prof. dr hab. Leszek Ga- } \\
\text { wor }\end{array}$ & bioetyka, filozofia \\
\hline & & $\begin{array}{l}\text { prof. dr hab. Joanna } \\
\text { Kostecka }\end{array}$ & $\begin{array}{l}\text { ochrona środowiska, gospo- } \\
\text { darka odpadami }\end{array}$ \\
\hline & & dr Barbara Fura & $\begin{array}{l}\text { ekonomika ochrony środo- } \\
\text { wiska }\end{array}$ \\
\hline Słupsk & $\begin{array}{l}\text { Wyższa Hanzeatycka Szko- } \\
\text { ła Zarządzania w Słupsku }\end{array}$ & $\begin{array}{l}\text { dr Agnieszka Sałek- } \\
\text { Imińska }\end{array}$ & $\begin{array}{l}\text { ekonomika ochrony środo- } \\
\text { wiska, gospodarka morska }\end{array}$ \\
\hline \multirow[t]{7}{*}{ Szczecin } & \multirow[t]{6}{*}{ Uniwersytet Szczeciński } & dr hab. Barbara Kryk & $\begin{array}{l}\text { ekonomika ochrony środo- } \\
\text { wiska, ubóstwo energe- } \\
\text { tyczne, CSR }\end{array}$ \\
\hline & & dr hab. Marian Malicki & $\begin{array}{l}\text { ekonomika gospodarki żyw- } \\
\text { nościowej }\end{array}$ \\
\hline & & dr Anna Katoła & ekonomika rozwoju trwałego \\
\hline & & dr Lidia Kłos & gospodarka wodna \\
\hline & & dr Grażyna Leśniewska & $\begin{array}{l}\text { komunikacja społeczna, so- } \\
\text { cjologia pracy }\end{array}$ \\
\hline & & dr Beata Skubiak & polityka regionalna \\
\hline & $\begin{array}{l}\text { Zachodniopomorski Uni- } \\
\text { wersytet Technologiczny }\end{array}$ & $\begin{array}{l}\text { dr Wojciech Zbaraszew- } \\
\text { ski }\end{array}$ & $\begin{array}{l}\text { finansowanie ochrony środo- } \\
\text { wiska }\end{array}$ \\
\hline \multirow[t]{11}{*}{ Warszawa } & $\begin{array}{l}\text { Akademia Leona Koźmiń- } \\
\text { skiego }\end{array}$ & dr hab. Lech Zacher & $\begin{array}{l}\text { futurologia, socjologia orga- } \\
\text { nizacji }\end{array}$ \\
\hline & $\begin{array}{l}\text { Akademia Pedagogiki Spe- } \\
\text { cjalnej }\end{array}$ & $\begin{array}{l}\text { prof. dr hab. Włodzi- } \\
\text { mierz Tyburski }\end{array}$ & $\begin{array}{l}\text { etyka, historia filozofii, bioe- } \\
\text { tyka }\end{array}$ \\
\hline & \multirow{4}{*}{$\begin{array}{l}\text { Instytut Ekonomiki Rolnic- } \\
\text { twa i Gospodarki Żywno- } \\
\text { ściowej Państwowy Instytut } \\
\text { Badawczy }\end{array}$} & prof. dr hab. Józef Zegar & $\begin{array}{l}\text { rolnictwo zrównoważone, } \\
\text { ekonomika ochrony środo- } \\
\text { wiska }\end{array}$ \\
\hline & & dr Konrad Prandecki & $\begin{array}{l}\text { rolnictwo zrównoważone, } \\
\text { ekonomika środowiska natu- } \\
\text { ralnego }\end{array}$ \\
\hline & & dr Barbara Wieliczko & $\begin{array}{l}\text { usługi ekosystemów, rolnic- } \\
\text { two zrównoważone }\end{array}$ \\
\hline & & dr Wioletta Wrzaszcz & rolnictwo zrównoważone \\
\hline & \begin{tabular}{|l|} 
Instytut Meteorologii i Gos- \\
podarki Wodnej Państwo- \\
wy Instytut Badawczy
\end{tabular} & $\begin{array}{l}\text { prof. dr hab. Jerzy } \\
\text { Zwoździak }\end{array}$ & $\begin{array}{l}\text { ekologistyka, zarządzanie } \\
\text { ochroną środowiska }\end{array}$ \\
\hline & $\begin{array}{l}\text { Instytut na Rzecz Ekoro- } \\
\text { zwoju }\end{array}$ & dr Andrzej Kassenberg & $\begin{array}{l}\text { planowanie przestrzenne, } \\
\text { polityka środowiskowa }\end{array}$ \\
\hline & $\begin{array}{l}\text { Polska Akademia Nauk } \\
\text { Komitet Prognoz „Polska } \\
\text { 2000 Plus” } \\
\end{array}$ & dr Artur Michałowski & $\begin{array}{l}\text { ekonomika środowiska, eko- } \\
\text { logia, zarzadzanie ochroną } \\
\text { środowiska }\end{array}$ \\
\hline & \begin{tabular}{|l|} 
Polska Akademia Nauk \\
Instytut Nauk Prawnych \\
\end{tabular} & $\begin{array}{l}\text { prof. dr hab. Wojciech } \\
\text { Radecki }\end{array}$ & prawo ochrony środowiska \\
\hline & $\begin{array}{l}\text { Szkoła Główna Gospodar- } \\
\text { stwa Wiejskiego }\end{array}$ & $\begin{array}{l}\text { prof. dr hab. Irena Ję- } \\
\text { drzejczyk }\end{array}$ & $\begin{array}{l}\text { finanse i ubezpieczenia, eko- } \\
\text { nomika turystyki }\end{array}$ \\
\hline
\end{tabular}




\begin{tabular}{|c|c|c|c|}
\hline & & $\begin{array}{l}\text { prof. dr hab. Edward } \\
\text { Majewski }\end{array}$ & ekonomika rolnictwa \\
\hline & \multirow[t]{2}{*}{ Szkoła Główna Handlowa } & $\begin{array}{l}\text { prof. dr hab. Adam Bud- } \\
\text { nikowski }\end{array}$ & $\begin{array}{l}\text { międzynarodowe stosunki } \\
\text { gospodarcze }\end{array}$ \\
\hline & & dr hab. Piotr Jeżowski & $\begin{array}{l}\text { ekonomia środowiska, poli- } \\
\text { tyka energetyczna }\end{array}$ \\
\hline & \multirow[t]{2}{*}{$\begin{array}{l}\text { Uniwersytet im. Kardynała } \\
\text { Stefana Wyszyńskiego }\end{array}$} & $\begin{array}{l}\text { ks. dr hab. Zbigniew } \\
\text { Lepko }\end{array}$ & $\begin{array}{l}\text { antropologia, etyka środowi- } \\
\text { skowa }\end{array}$ \\
\hline & & $\begin{array}{l}\text { ks. dr hab. Ryszard Sa- } \\
\text { dowski }\end{array}$ & $\begin{array}{l}\text { antropologia środowiskowa, } \\
\text { filozofia środowiskowa }\end{array}$ \\
\hline & \multirow[t]{4}{*}{ Uniwersytet Warszawski } & $\begin{array}{l}\text { prof. dr hab. Tomasz } \\
\text { Żylicz }\end{array}$ & $\begin{array}{l}\text { ekonometria, mikroekono- } \\
\text { mia, ekonomia środowiska, } \\
\text { ekonomia ekologiczna }\end{array}$ \\
\hline & & $\begin{array}{l}\text { dr hab. Mikołaj Czaj- } \\
\text { kowski }\end{array}$ & $\begin{array}{l}\text { ekonomika środowiska natu- } \\
\text { ralnego, mikroekonomia }\end{array}$ \\
\hline & & dr hab. Jerzy Śleszyński & $\begin{array}{l}\text { ekonomika ochrony środo- } \\
\text { wiska, polityka ochrony śro- } \\
\text { dowiska }\end{array}$ \\
\hline & & dr Mikołaj Niedek & $\begin{array}{l}\text { nauki filozoficzne, rozwój } \\
\text { trwały }\end{array}$ \\
\hline & \multirow{2}{*}{$\begin{array}{l}\text { Wyższa Szkoła Ekologii } \\
\text { i Zarządzania w Warszawie }\end{array}$} & dr Jan Cetner & turystyka zrównoważona \\
\hline & & dr Kazimierz Dyguś & $\begin{array}{l}\text { ekologia roślin, turystyka } \\
\text { zrównoważona }\end{array}$ \\
\hline \multirow[t]{12}{*}{ Wrocław } & \multirow[t]{2}{*}{ Politechnika Wrocławska } & dr Lukasz Szałata & $\begin{array}{l}\text { inżynieria i ochrona środo- } \\
\text { wiska }\end{array}$ \\
\hline & & dr Magdalena Węglarz & gospodarka energetyczna \\
\hline & \multirow[t]{9}{*}{$\begin{array}{l}\text { Uniwersytet Ekonomiczny } \\
\text { we Wrocławiu }\end{array}$} & $\begin{array}{l}\text { prof. dr hab. Bogusław } \\
\text { Fiedor }\end{array}$ & $\begin{array}{l}\text { teoria ekonomii, ekonomika } \\
\text { środowiska naturalnego }\end{array}$ \\
\hline & & $\begin{array}{l}\text { prof. dr hab. Stanisław } \\
\text { Czaja }\end{array}$ & $\begin{array}{l}\text { teoria ekonomii, ekonomika } \\
\text { środowiska naturalnego, hi- } \\
\text { storia myśli ekonomicznej }\end{array}$ \\
\hline & & $\begin{array}{l}\text { prof. dr hab. Andrzej } \\
\text { Graczyk }\end{array}$ & $\begin{array}{l}\text { ekonomika środowiska natu- } \\
\text { ralnego, gospodarka energe- } \\
\text { tyczna, mikroekonomia }\end{array}$ \\
\hline & & $\begin{array}{l}\text { dr hab. Bożena Ryszaw- } \\
\text { ska }\end{array}$ & $\begin{array}{l}\text { ekonomia ekologiczna, zielo- } \\
\text { na gospodarka }\end{array}$ \\
\hline & & dr hab. Anetta Zielińska & $\begin{array}{l}\text { inżynieria i ekonomika och- } \\
\text { rony środowiska }\end{array}$ \\
\hline & & $\begin{array}{l}\text { dr hab. Karol Kociszew- } \\
\text { ski }\end{array}$ & ekonomia ekologiczna \\
\hline & & dr Agnieszka Becla & $\begin{array}{l}\text { teoria ekonomii, ekonomia } \\
\text { ekologiczna }\end{array}$ \\
\hline & & dr Agnieszka Ciechelska & $\begin{array}{l}\text { ekonomika ochrony środowis- } \\
\text { ka i zasobów naturalnych }\end{array}$ \\
\hline & & dr Alicja Graczyk & $\begin{array}{l}\text { gospodarowanie środowiskiem } \\
\text { i energią }\end{array}$ \\
\hline & $\begin{array}{l}\text { Wyższa Szkoła Bankowa } \\
\text { we Wrocławiu }\end{array}$ & dr hab. Johannes Platje & $\begin{array}{l}\text { mikro- i makroekonomia, } \\
\text { ekonomia ekologiczna }\end{array}$ \\
\hline
\end{tabular}

Źródło: opracowanie własne. 


\section{Podsumowanie}

Wieloletnie, gdyż trwające już ponad pół wieku, badania nad rozwojem trwałym skłaniają do pewnych podsumowań i oceny zachodzących procesów. Stale rosnące zainteresowanie problematyka, inwencja badaczy, uzyskiwane awanse naukowe i wdrażanie elementów rozwoju trwałego są powodem do pozytywnego myślenia o przyszłym rozwoju cywilizacyjnym Polski. Jednak optymizm ten jest umiarkowany, a wpływ mają na to następujące czynniki:

- $\quad$ niedostatek w społeczeństwie pełnej i rzetelnej wiedzy na temat rozwoju trwałego, co powoduje zniechęcenie do podejmowania działań na rzecz lepszego bytu przyszłych pokoleń;

- decyzje podejmowane przez polityków, które nierzadko promują wzrost gospodarczy, zamiast dążenia do poprawy jakości życia, bowiem horyzont czasowy decyzji polityków dotyczy zwykle tylko kolejnych wyborów - są skoncentrowane na rozwiązywaniu jedynie bieżących problemów, przez co pozostają w sprzeczności z zasadą sprawiedliwości międzypokoleniowej [Naisbitt, 2015, s. 3];

- niedobór myślenia i planowania strategicznego, co wynika z bezkrytycznej wiary w mechanizm rynkowy i braku zapotrzebowania na długookresowe prognozy ze strony polityków [Mączyńska, 2013, s. 20];

- $\quad$ trwające nadal wśród naukowców spory terminologiczne, które dodatkowo potęgują szum informacyjny wokół rozwoju trwałego;

- $\quad$ widoczna luka pokoleniowa wśród specjalistów rozwoju trwałego - o ile w okresie fascynacji szybko rosła liczba młodych naukowców, organizowanych konferencji i ich uczestników, o tyle obecnie obserwowana wcześniej dynamika nieco osłabła.

Niekorzystnej tendencji może zaradzić dalsza intensywna edukacja społeczeństwa i promocja badań stosowanych. Działania te powinny sprawić, że rozwój trwały nie będzie już tylko teoretycznym modelem, a stanie się powszechnie zrozumiałym, godnym realizacji i nieutopijnym kierunkiem rozwoju cywilizacyjnego.

Wezwanie do intensyfikacji badań stosowanych nie oznacza definitywnego zamknięcia początkowych etapów prac nad rozwojem trwałym i rezygnacji ze ściśle teoretycznych rozważań. Jak podkreślił Tadeusz Borys, zaniechanie badań podstawowych prowadzi do wyjałowienia nauki [Borys, 2016]. Prowadzenie badan podstawowych stanowi takize intelektualny zaçyn pomystón jak najbardziej praktycznych, które wyprzedzaja swoja epoke [Jajszczyk, 2016]. Ponadto, obecny stan wiedzy daje podstawę do wyjaśnienia wielu teoretycznych zagadnień, których wcześniej nie można było rozstrzygnąć lub nie występowały z taką intensywnościa jak współcześnie. Wyzwania te, jak pokazano w przeprowadzonej kwerendzie, coraz częściej podejmują młodzi naukowcy.

\section{Wkład autorów w powstanie artykułu}

prof. dr hab. Kazimierz Górka - 50\%

dr hab. inż. Marcin Łuszczyk, prof. PO - 50\% 


\section{Literatura}

Borys T., 2004, Pomiar trwałego i zrównoważonego rozwoju, [w:] Uwarunkowania i mechanizmy z̧równoważonego rozwoju, Wydawnictwo Wyższej Szkoły Ekonomicznej w Białymstoku, Białystok-Supraśl.

Borys T., 2005, W askie i szerokie interpretacje zrównoważonego rozwoju oraz konsekwencje wyboru, [w:] Zrównoważony rozwój. Od utopii do praw człowieka, A. Papuziński (red.), Oficyna Wydawnicza Branta, Bydgoszcz.

Borys T., 2010, Koncepcja zrównoważonego rozwoju w naukach ekonomicznych, [w:] Edukacja dla zrónnoważonego rozwoju. Edukacja dla ładu ekonomicznego, B. Poskrobko (red.), Wydawnictwo Ekonomia i Środowisko, Białystok-Wrocław.

Borys T., 2011, Zrównoważony rozwój - jak rozpoznać lad zintegrowany, „Problemy Ekorozwoju", nr 2.

Borys T., 2016, Wypowiedźpodczas Ogólnopolskiej Konferencji Naukowej pt.: Zasoby naturalne a rozwój zrównoważony i trwaty, Kraków 20-21.11.2016 roku.

Borys T., Czaja S., 2009, Badania nad zrównoważonym rozwojem w polskich ośrodkach naukowych, [w:] Od koncepcji ekorozwoju do ekonomii zrównoważonego rozwoju, D. Kiełczewski (red.), Wydawnictwo Wyższej Szkoły Ekonomicznej w Białymstoku, Białystok.

Brundtland G. H., 1991, Report of the World Commission on Environment and Development: Our Common Future, United Nations, A/42/427, wydanie polskie: Nasza wspólna prayszłość. Raport Światowej Komisji ds. Środowiska i Rozwoju (Raport G. H. Brundtland), Polskie Wydawnictwo Ekonomiczne, Warszawa.

Carlowitz H. C., 2009, Sylvicultura Oeconomica. Hausswirthliche Nachricht und Naturmäßige Anweisungzur Wilden Baum-Zucht, Reprint der zweiten Auflage von 1732, Verlag Kessel, Remagen-Oberwinter.

Czaja S., 2011, Kategoria czasu w ekonomii zrównoważonego rozwoju oraz gospodarce opartej na wiedzy, [w:] Uwarunkowania rozwoju zrównoważonej gospodarki opartej na wiedzy, B. Poskrobko (red.), Wydawnictwo Wyższej Szkoły Ekonomicznej w Białymstoku, Białystok.

Dołęga J. M., 2000, Z zagadnień filozofii nauk ekologicznych, „Studia Teologiczne”, nr 18.

Goetel W., 1996, Sozologia - nauka o ochronie prayrody i jej zasobów, „Kosmos”, nr 15.

Górka K., 1997, Ekonomiczne aspekty gospodarowania odpadami przemystowymi i komunalnymi, „Ochrona Powietrza i Problemy Odpadów”, nr 5.

Górka K., 2013, 40 lat problematyki ekonomicznej w AURZE, „Aura”, nr 3.

Górka K., 2013, Tendencje rozwoju mezoekonomii w Polsce w wyniku zmian ustrojouych $i$ zmian cymilizacyjnych. Referat na IX Kongres Ekonomistów Polskich pt.: Ekonomia dla prayszłłości. Odkerywaí nature $i$ prayczyny zjawisk gospodarczych, Warszawa 28-29.11.2013 roku, http://www.kongres.pte.pl/kongres/upload/files/ (data wejścia: 20.08.2016).

Górka K., Luszczyk M., 2014, Roz̨ój trwaty i zrównoważony w przestrzeni wirtualnej, [w:] Meandry współpracy sieciowej w Europie Środkowej $i$ Wschodniej, S. Partycki (red.), Wydawnictwo Katolickiego Uniwersytetu Lubelskiego, Lublin.

Herer W., Sadowski W., 1989, Zderzenia z barierami rozwoju, Polskie Wydawnictwo Ekonomiczne, Warszawa. 
Jajszczyk A., 2012, Badania podstawowe, ale nie bezuisyteczne, https://www.ncn.gov.pl/ sites/default/files/pliki/centrum-prasowe/2012.07.18-GW-badania-podstawowe.pdf (data wejścia: 12.10.2016).

Jonas H., 1996, Zasada odpowiedzialności, Platan, Kraków.

Kiełczewski D., 2013, Kapitał kulturowy jako przedmiot $i$ wyžwanie teorii zrównoważonego rozwoju, „Handel Wewnętrzny”, listopad-grudzień.

Kozłowski S., 1996, C:y transformacja polskiej gospodarki zmierza w kierunku rozwoju zrównoważonego, [w:] Mechanizmy i uwarunkowania ekorozwoju, t. I, S. Wrzosek (red.), Wydawnictwo KEiZOŚ Politechniki Białostockiej, Białystok.

Kuzior A., 2006, Cztowiek jako racjonalny podmiot driatań w świetle zatożen koncepsii zrównoważonego rozwoju, „Problemy Ekorozwoju”, nr 2.

Leontief W., 1984, Structure of the World Economy, "The American Economic Review", no. 6 .

Ludrie nauki - baza danych OPI, http://www.nauka-polska.pl/Bazy-danych.html (data wejścia: 12.10.2016).

Mączyńska E., 2013, IX Kongres Ekonomistón Polskich. Nauki ekonomiczne i praktyka gospodarcza w zmieniajacym sie świecie, „Biuletyn PTE”, nr 4 (63).

Mishan E.J., 1967, Costs of Economic Growth, Frederick A. Praeger, New York.

Naisbitt J., 2015, Der Horizont reicht meist nurbis zum nächsten Wabltag, „Aus der Politik und Zeitgeschichte", nr 31-32.

Papuziński A., 2013, Aksjologia zrównoważonego rozpoju: próba typologizacji, „Problemy Ekorozwoju", nr 1.

Piątek Z., 1998, Etyka środowiskowa. Nowe spojrzenie na miejsce człtowieka w prayrodzie, Wydawnictwo Instytutu Filozofii Uniwersytetu Jagiellońskiego, Kraków.

Poskrobko B., 1998, Ekorozwój jako podstawa aplikacyjnych założen polityki ekologicznej, [w:] Ocbrona środowiska. Problemy spoteczne, ekonomiczne i prawne, K. Górka, B. Poskrobko, W. Radecki (red.), Polskie Wydawnictwo Ekonomiczne, Warszawa.

Problems of the Human Environment 1969 A/RES/2398 (XXIII), [w:] Resolutions adopted by the General Assembly during its 23rd session, Supplement, no. 18 (A/7218), United Nations, New York.

Report of the United Nations Conference on the Human Environment, 1972, A/CONF. 48/14/Rev. 1, United Nations, Stockholm.

Sztumski W., 2008, Refleksja na temat zrównoważonego rozwoju (Cayy zrównoważony rozwój jest fikcja, utopiq, ilurja çy oszustwem?), „Problemy Ekorozwoju”, $\mathrm{nr} 2$.

Uchwała Sejmu Rzecryppospolitej Polskiej z. dnia 10 maja 1991 roku w sprawie polityki ekologicznej, M.P. 1991, Nr 18, poz. 118.

Zacher L. W., 2008, Trwaly rožoój-utopia casy realna możliwość? „Problemy Ekorozwoju", nr 2 . 